\title{
EFFECTS OF INDUCED MATERNAL HYPOTHYROIDISM ON THE OVARIAN DEVELOPMENT OF OFFSPRING RATS
}

RADOVANOVIĆ ANITA, ROKSANDIĆ D, ŠIMIĆ MARIJA, MARKOVIĆ DANICA and GLEDIĆ D

University of Belgrade, Faculty of Veterinary Medicine, Serbia

$$
\text { (Received 27th April 2012) }
$$

The effects of propylthyouracil (PTU) induced hypothyroidism of rats during pregnancy and lactation on offspring ovarian development and maturation were studied. Thyroid hormones and thyroid stimulating hormone (TSH) concentrations were determined using the radioimmunoassay method in order to verify the hypothyroid status of treated mothers and their two months old pups. The ovaries of the offspring were processed for light microscopy analysis on the day of the first estrus after the $60^{\text {th }}$ day of age. Histological analysis including follicle count was performed on serial sections stained with haematoxyline/eosin and on semithin sections stained with methylene blue. A significant increase of serum TSH and decrease in $T_{3}$ and $T_{4}$ levels was observed in treated mothers compared to controls. The levels of measured hormones in the control and PTU-treated two months old rats were not significantly different. Ten percent of 60-dayold treated females did not reach estrus and they were sacrificed in diestrus. The secondary interstitial cells were the dominant structures in the ovaries. The number of healthy growing and early antral follicles was markedly decreased. Ovaries of treated rats contained relatively few antral follicles, significantly more atretic antral follicles and a decreased number of corpora lutea, compared to controls. These results indicate that lack of thyroid hormones during prenatal and early postnatal development impair ovarian development in rats.

Key words: hypothyroidism, ovarian development, rat

\section{INTRODUCTION}

It is well documented that thyroid hormones are important for normal embrional and postnatal development of humans and animals and function of physiological systems later in life (Fowden and Forhead, 2004; Fowden et al., 2006; Zahediasl, 2010). This is most evident in the central nervous system where thyroid hormone deficiency during early fetal and neonatal periods results in congenital hypothyroidism which is characterized by generalized delay in brain growth (Porterfield and Hendrich, 1993), delayed neural and glial cell differentiation and migration (Nicholson and Altman, 1972), and diminished 
dendritic branching and elongation (Lauder, 1977; Ipina et al., 1987). Even transient undiagnosed maternal hypothyroidism can lead to measurable neurological deficits in the offspring despite the lack of neonatal hypothyroidism (Dowling et al., 2001).

Current evidence suggests functional interrelationships between hypothyroidism and disturbances in the development of gonads. For example, neonatal and juvenile transient hypothyroidism prolongs postnatal Sertoli cell mitogenesis (Holsberger et al., 2003) induces macroorchidism, increases the number of Sertoli, Leydig, and germ cells (Maran, 2003) in a dose dependant manner (Cristovao et al., 2002). Our previous results indicated that hypothyroidism induced with very low doses of 6-propyl-2-thyouracil during pregnancy and lactation promoted changes in the Sertoli cells and resulted in disorders of germ cell differentiation control and maturation of the testicles of juvenile pups (Stošić-Bogdanović and Radovanović, 1992).

In addition, it was demonstrated that hypothyroidism, causes among other factors, ovarian atrophy with disturbed folliculogenesis and absence of corpora lutea (Ortega et al., 1990; Dijkstra et al., 1996) or polycystic ovaries (Bagavandoss et al., 1998). In our previous investigations it was shown that maternal hypothyroidism during pregnancy and lactation increased the number of atretic follicles in all stages of folliculogenesis in ovaries of 15- and 30-day-old rats, compared to control animals. Most prominent changes were in the population of antral follicles. Degenerative changes were seen in the granulosa cells, segmented oocytes and theca interstitial cells, while secondary interstitial cells were hypertrophic (Radovanović, 1993; Radovanović, 2003).

The aim of this study was to describe changes in the ovaries of pubertal rats, whose mothers were exposed to PTU during pregnancy and lactation.

\section{MATERIAL AND METHODS}

Female inbred Albino-Oxford rats were housed in the animal facility under standard laboratory conditions with free access to food and water and light/dark ratio 12/12. Vaginal smears were taken daily for two weeks between 8:00 and 10:00 a.m. and stained with haematoxyline/eosin and subsequently were examined for the determination of the cycle stage. Only females demonstrating 2 or 3 consecutive, 4-day cycles were mated. The day when the vaginal plug was discovered was considered as gestation day 0 . A group of seven mothers was treated with 6-n-propyl-2-thyouracil (PTU), as $1.5 \mathrm{mg} / \mathrm{L}$ solution in drinking water from the beginning of pregnancy and during lactation, until the pups were weaned. The control group of six mothers received tap water. After weaning (30th postnatal day) control and treated mothers were sacrificed and blood samples were collected. The offsprings were housed until the end of the experiment with no addition of PTU. The offspring females from the control $(n=7)$ and treated groups $(n=6)$ were sacrificed on the day of the first estrus (E-day) after 60 days of age. The determination of the estrus cycle phase was performed in the same manner as it was for the mothers. Ten percent of treated animals did not reach estrus until the 68th day and they were sacrificed in diestrus. 
Acta Veterinaria (Beograd), Vol. 62, No. 5-6, 483-493, 2012.

\section{Blood samples}

The blood samples of control and PTU-treated mothers and daughters on Eday were collected for the estimation of thyroid hormones and $\mathrm{TSH}$. Hormone concentrations of $T_{4}$ and $T_{3}$ in the serum were determined using commercial radioimmunoassay (RIA) kits (INEP-Zemun). The serum TSH concentrations were determinated using rTSH RIA immunoreagents kindly supplied by Dr Parlow on behalf of the National Hormone and Pituitary Program (NHPP).

Histological analysis

The ovaries were weighed and fixed in Bouin solution and embedded in paraffin. Histological analysis including follicle count was performed on $5 \mu \mathrm{m}$ thick serial sections stained with haematoxyline/eosin.

For semithin sections, pieces of ovaries immediately after isolation were fixed in cold $4 \%$ glutaraldehyde buffered in Milloning, postfixed in $1 \%$ buffered osmic acid and embedded in araldite. Sections, $1 \mu \mathrm{m}$ thick, were stained with methylene blue and cytological characteristics of follicular structures, interstitial and luteal cells were examined using light microscopy.

Morphometric measurements

Based on morphological and cytological criteria, healthy and atretic follicles were classified as: primary, growing, early antral and antral follicles and counted on every fifth section. Number and mean diameter of corpora lutea were measured, also.

\section{Statistical analysis}

The Student's t-test was used for evaluation of statistical significance of all the results between groups. Differences of $p<0.05$ were considered statistically significant.

\section{RESULTS}

Hormone concentration. Serum concentration of TSH was significantly increased and concentration of tri-iodothyronine and thyroxine was decreased in PTU-treated mothers as compared to euthyroid mothers (Figure 1).

The levels of measured hormones in treated descendents on E-day were similar to those of corresponding controls (Figure 1). The observed differences were not statistically significant.

Body mass. The average body mass of treated pups was not significantly changed (control: $122.43 \pm 2.26 \mathrm{~g}$, treated: $115.61 \pm 3.47 \mathrm{~g}$ ) but, while there were no respective individual variations, in the group of control animals, two subgroups formed in the group of treated 60-day-old. The body mass in one group (23.08\% individuals) was lower than the lowest value of controls and equaled, on average $92.67 \pm 1.33 \mathrm{~g}^{* * *}$. The average mass of $15.38 \%$ was higher than the highest in the control group $\left(145.5 \pm 2.1 \mathrm{~g}^{\star \star *}\right)$.

Average ovarian mass was significantly reduced $(p<0.05)$ in PTU-treated rats $(59.99 \pm 3.76 \mathrm{mg})$ compared to the control group $(74.2 \pm 5.60 \mathrm{mg})$. 
Acta Veterinaria (Beograd), Vol. 62, No. 5-6, 483-493, 2012. Radovanović Anita et al.: Effects of induced maternal hypothyroidism on the ovarian development of offspring rats

Analysis of vaginal smears showed that $10 \%$ of treated animals did not reach estrus until the 68th day and they were sacrificed in diestrus.
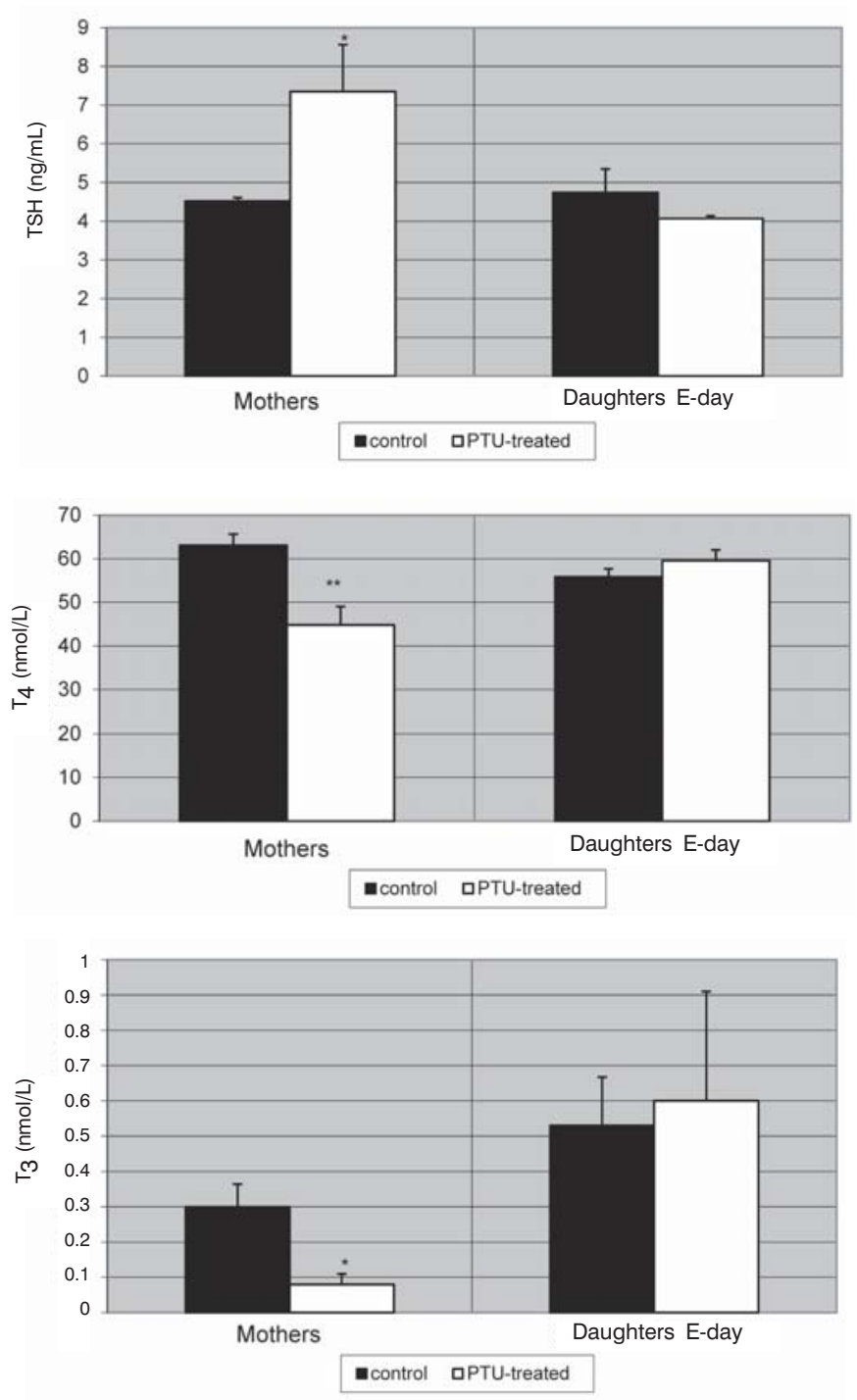

Figure 1. Serum concentrations of TSH, $\mathrm{T}_{4}$ and $\mathrm{T}_{3}$ in control (C) and PTU-treated mothers and daughters on E-day $\left({ }^{*}-p<0.05,{ }^{* *}-p<0.01\right)$ 
Histological examination. In the ovaries of control animals the cortex and medulla are clearly distinguishable (Figure 2). The cortex contains follicles at different stages of development and atresia, corpora lutea and sparse interstitial cells between follicles. Interstitial cells (IC) are mostly in the medulla, forming clusters which are separated by undifferentiated stromal cells. Vesicles of different size were seen mostly at the periphery of pale cytoplasm of interstitial cells. Many lipid droplets are seen in the intercellular and perivascular spaces (Figure 3).

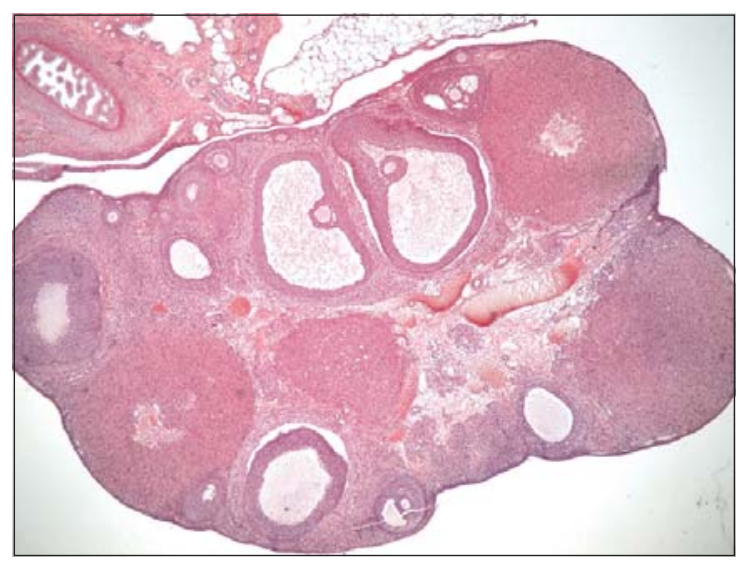

Figure 2. Ovary of control rat, clearly distinguishable cortex and medulla, follicles at different stages of development and atresia, corpora lutea and sparse interstitial cells between follicles, HE x 4

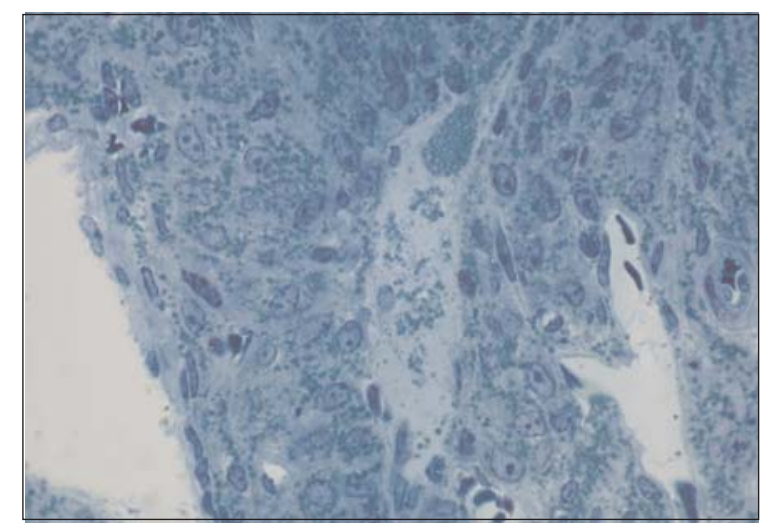

Figure 3. Semithin section of interstitial cells of contol rat, methylene blue, $x 40$

Ovaries of treated rats showed that the follicles are mostly in the deeper ovarian cortex, comparing to control animals. Medulla and cortical stroma contain 
an unusually large amount of interstitial tissue (Figure 4). Most of the interstitial cells are large and polyhedral in shape and contain an abundance of closely packed lipid vesicles, relatively uniform in size (Figure 5).

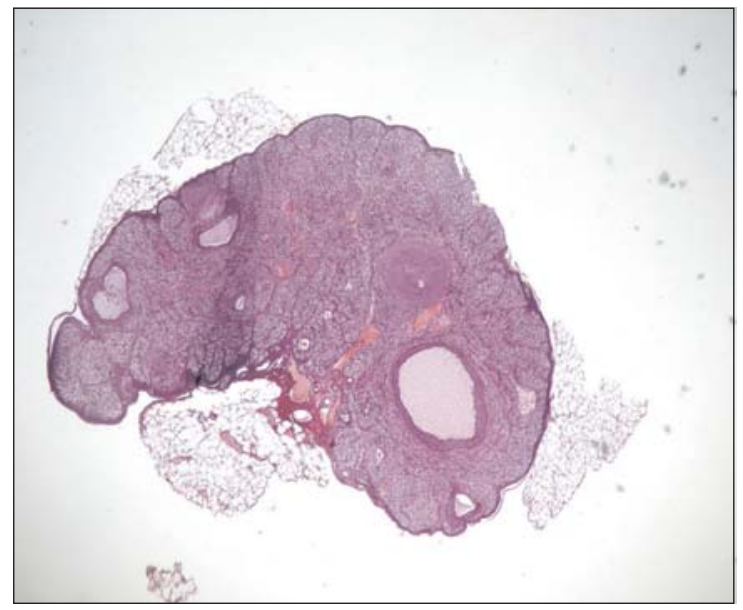

Figure 4. Ovaries of treated rats, follicles are mostly in deeper ovarian cortex, large amount of interstitial tissue in cortex and medulla, HEx4

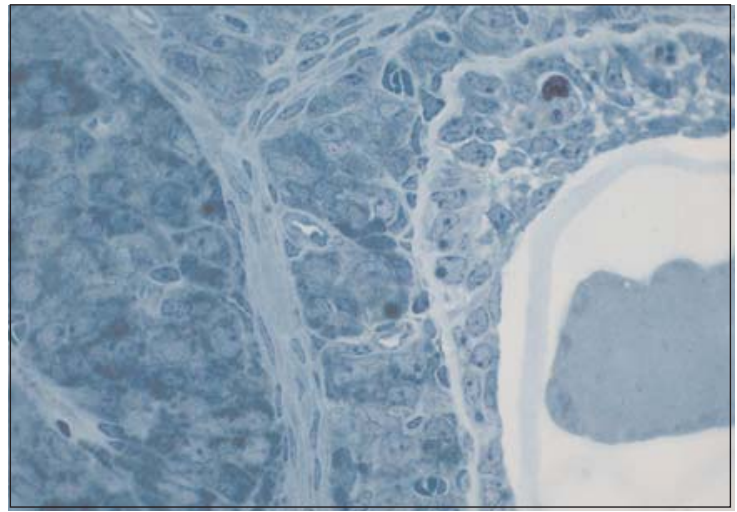

Figure 5. Semithin section of atretic follicle and interstitial cells in ovary of treated rat, methylene blue, $x 40$

Morphometric analysis. The number of activated ovarian follicles was significantly reduced in treated animals $(p<0.05)$. During initial recruitment there was no appreciable difference, but the dynamic of later ovarian follicle development has been changed. The number of healthy growing $(p<0.05)$ and early antral follicles $(p<0.001)$ was markedly decreased in treated rats. Ovaries of PTU-treated animals contained relatively fewer antral follicles and significantly more atretic antral follicles $(p<0.05)$ compared to controls (Figure 6). 
Acta Veterinaria (Beograd), Vol. 62, No. 5-6, 483-493, 2012.

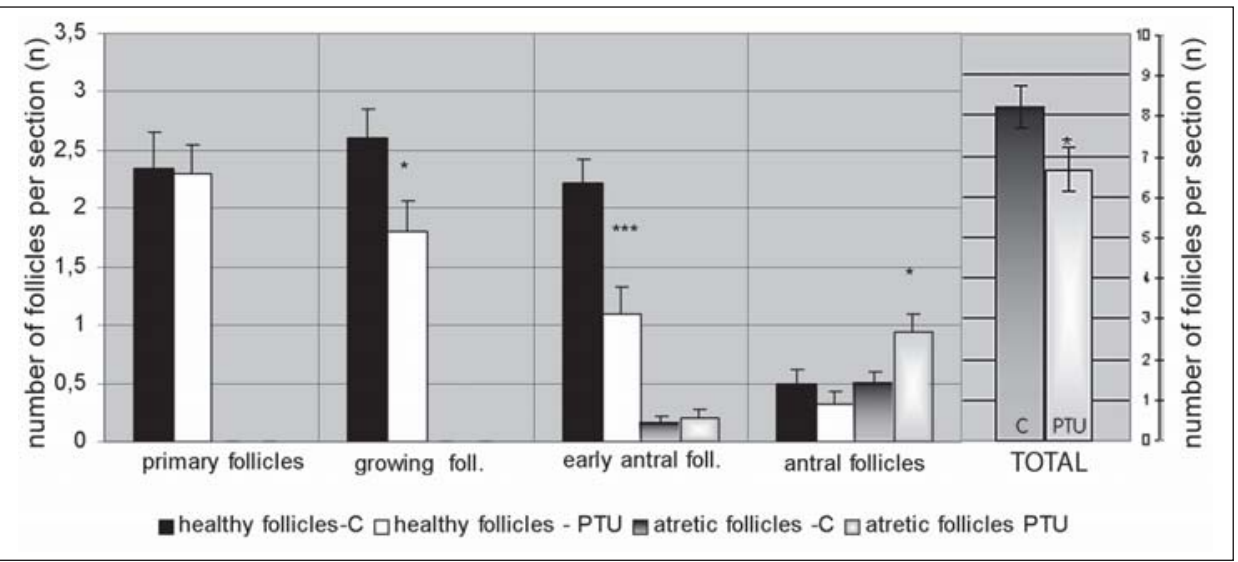

Figure 6. Number of follicles in ovaries of control (c) and PTU-treated (PTU) rats $\left({ }^{*}-p<0.05,{ }^{* *}-p<0.001\right)$

In the ovaries of $10 \%$ of treated animals which did not reach estrus, there were no corpora lutea. In the ovaries of the remaining $90 \%$ of treated rats, significantly fewer corpora lutea were found $(p<0.001)$. There were no differences in the mean diameter of $\mathrm{CL}$ of treated animals compared to controls $(670 \pm 2.91 \mu \mathrm{m}$ and $650 \pm 4.37 \mu \mathrm{m}$, respectively).

\section{DISCUSSION}

Hypothyroidism is the most frequent endocrine disorder in the early period of development in humans and animals. However, the mechanisms, and even all the consequences on mammalian litters caused by hypothyroidism of the mother during pregnancy and lactation have not been completely understood. It was stated that the human and rat fetus is completely independent from the mother's thyroid hormones because they do not pass the placental barrier until the last third of pregnancy, in the period when the fetal thyroid gland is beginning its functional activity. The rat thyroid gland secrete thyroid hormones about day 17 p.c. At the same time thyrotropic cells in the adenohypophysis are identified for the first time (Begeot et al., 1981; Dussault and Labrie, 1975). Later examinations revealed that thyroid hormones can be demonstrated in rat embrionic tissues using RIA 4 days after uterine implantation (Obregon et al., 1984) and their receptors on embrionic days 13-14 (Falcone et al., 1994). This would suggest the transplacental origin of these hormones, and potential influence of mother's thyroid hormones on fetuses. In our experiment, increased TSH and reduced serum $\mathrm{T}_{4}$ and $\mathrm{T}_{3}$ concentration, have shown a hypothyroid status in treated mothers. However, the levels of measured hormones on E-day were not significantly different between control and PTU-treated rats, but a small increase in serum $T_{3}$ and $T_{4}$ with modestly decreasing concentration of TSH was seen. 
We have previously shown a significant increase of serum TSH and decrease in $T_{3}$ and $T_{4}$ level in 15-day-old treated rats under equal experimental conditions. Thirty-day-old treated rats had normal serum $\mathrm{T}_{3}$ and $\mathrm{T}_{4}$ with markedly elevated TSH compared to controls (Radovanović, 2003). Similar results were obtained by Stephan et al. (1993) who demonstrated that the methimazoletreated pups were hypothyroid, with markedly higher TSH and lower $\mathrm{T}_{4}$ concentrations, until weaning, after which they transiently became hyperthyroid at week five, but returned to euthyroid state at week six.

It has also been noted in our present study that PTU treatment results in decreased body mass. While in control animals there were no remarkable individual variations, in the treated group, two subgroups formed animals (23.08\%) whose body mass was lower from the lowest value of the control, and a subgroup with an average mass $15.38 \%$ higher than the highest in the control group. Zertashia et al. (2002) reported that body weight of offspring in the postnatal PTU-treated group ( $0.1 \%$ PTU) was significantly decreased, while prenatal PTU-treatment induced a significant increase in prepubertal and pubertal rats compared to the control group. Furthermore, in our experimental model in $10 \%$ of animals ovulation did not occur until the 68th day, when they were sacrificed. These rats belong to the subgroup with the lowest body mass. All treated offspring showed reduction of ovarian mass, as a result of a decreased number of activated follicles and follicles which are able to ovulate and form corpora lutea. As a consequence of intensive follicular atresia in the previous period, secondary interstitial cells become dominant structures in the ovaries of treated animals (Radovanović, 1993; 2003).

The initial recruitment of follicles in the studied period is not affected in treated animals compared to controls, but dysfunction occurs in cyclic recruitment. This process starts in the secondary follicles when the theca folliculi is well developed, with functional receptors for gonadotrophic hormones (McGee and Huseh, 2000). These hormones, especially FSH, are important factors for the proliferation and survival of follicular somatic cells and the cyclic recruitment of antral follicles. FSH induced reduction of iRNA level for $\mathrm{p}-53$ protein, which conducts cells in apoptosis and intensifies Bax protein synthesis, without changes in Bcl2 protein expression (Tilly and Tilly, 1995). Asahara et al. (2003) demonstrated that $\mathrm{T}_{3}$ interacts synergistically with $\mathrm{FSH}$ to inhibit apoptosis in granulosa cells obtained from small follicles, without affecting proliferation of those cells. Oposite to FSH and $\mathrm{T}_{3}$, androgens synthesized by interstitial cells are important proapoptotic factors (Hsueh et al., 1994). In our experiment, with regard to the respectable amount of interstitial cells, this might be the cause of an increasing number of atretic preantral and antral follicles. Another reason for the diminished number of ovulated follicles can be an increased level of mRNA for inhibin in hypothyroid rats (Tamura et al., 1998). Inhibin suppresses oestradiol production and antagonizes activin actions and thus inhibits follicular growth and differentiation.

Our previous results concerning the effects of maternal hypothyroidism during pregnancy and lactation on the development of ovaries in 15- and 30-dayold rats indicate that hypothyroidism induced with propylthyouracil during the 
prenatal and early postnatal period caused an increased activation of follicles with an increased number of atretic follicles at all stages of folliculogenesis (most prominent in the population of antral follicles) compared to control animals (Radovanović, 2003).

According to clinical investigations, in hypothyroid women when T3 serum level is less than $80 \mathrm{ng} / \mathrm{dL}$, no ovulation can be induced (Maruo et al., 1992). It was shown that oocytes, cumulus and granulosa cells possess mRNA for thyroid receptors (TR $\alpha-1, \operatorname{TR}-\beta-1, \operatorname{Tr} \beta-2$ and c-erba $\alpha-2)$, and that concentration of free $T_{3}$ in the follicular fluid is similar to its blood concentration (Zhang et al., 1997). This suggests that proper receptors are necessary for thyroid hormones to exert a direct influence on normal differentiation of all structures in preovulatory follicles.

In human medicine was reported that untreated thyroid disease may induce problems associated with premature ovarian failure and menopause (Buckler, 2007). Reduction in the number of follicles and corpora lutea, and hyperplasia and hypertrophy of stromal interstitial cells which is a common feature of ovarian atrophy in ageing rodents (OECD, 2009), imply premature ovarian failure in the ovaries of 60- day-old rats in our experiment.

The results presented in this paper indicate that although PTU-treated rats during prenatal and early postnatal period become euthyroid at 60 days, ovarian development was evidently impaired.

ACKNOWLEDGMENT:

This work was supported by the Ministry of Science, Republic of Serbia (grant No. 175061).

Address for correspondence:

Anita Radovanović DVM, PhD

Department of Histology and Embryology

Faculty of Veterinary Medicine

University of Belgrade

11000 Belgrade, Serbia

E-mail: anita@vet.bg.ac.rs

\section{REFERENCES}

1. Asahara S, Sato A, Aljonaid AA, Maruo T, 2003, Thyroid hormone synergizes with follicle stimulating hormone to inhibit apoptosis in porcine granulosa cells selectively from small follicles, Kobe $J$ Med Sci, 49, 107-16.

2. Bagavandoss $P$, England B, Asirvatham A, Bruot BC, 1998, Transient induction of polycystic ovarylike syndrome in immature hypothyroid rats, Proc Soc Exp Biol Med, 219, 77-84.

3. Begeot M, Dupouy JP, Dubois MP, Dubois PM, 1981, Immunocytological determination of gonadotropic and thyrotropic cells in fetal rat anterior pituitary during normal development and under experimental conditions, Neuroendocrinol, 32, 285-94.

4. Buckler H, 2007, Thyroid disease and ovarian failure, Menopause Int, 13, 193.

5. Cristovao FC, Bisi H, Mendonca BB, Bianco AC, Bloise W, 2002, Severe and mild neonatal hypothyroidism mediate opposite effects on Leydig cells of rats, Thyroid, 12, 13-8.

6. Dijkstra G, de Rooij DG, de Jong FH, van den Hurk R, 1996, Effect of hypothyroidism on ovarian follicular development, granulosa cell proliferation and peripheral hormone levels in the prepubertal rat, Europ J Endocrinol, 134, 649-54. 
7. Dowling ALS, lannacone EA, Zoeller RT, 2001, Maternal Hypothyroidism Selectively Affects the Expression of Neuroendocrine-Specific Protein A Messenger Ribonucleic Acid in the Proliferative Zone of the Fetal Rat Brain Cortex, Endocrinol, 142, 390-9.

8. Dussault JH, Labrie F, 1975, Development of the hypothalamic-pituitary-thyroid axis in the neonatal life, Endocrinol, 97, 1321-4.

9. Falcone M, Takahide M, Fierro-Renoy F, Macchia E, Degroot LJ, 1994, Evaluation of the ontogeny of thyroid hormone receptor isotypes in rat brain and liver using an immunohystochemical technique, Europ J Endocrinol, 130, 97-106.

10. Fowden AL, Forhead AJ, 2004, Endocrine mechanisms of intrauterine programming, Reproduction, 127, 515-26.

11. Fowden AL, Giussani DA, Forhead AJ, 2006, Intrauterine programming of physiological systems: causes and consequences, Physiology, 21, 29-37.

12. Holsberger DR, Jirawatnotai S, Kiyokawa H, Cooke PS, 2003, Thyroid hormone regulates the cell cycle inhibitor p27Kip1 in postnatal murine Sertoli cells, Endocrinology, 144, 3719-21.

13. Hsueh AJW, Billing $H$, Tsafriri A, 1994, Ovarian follicle atresia, Hormonally controlled apoptotic process, Endocrine Rev, 15, 707-25.

14. Ipina SL, Ruiz-Marcos A, Escobar del Rey F, Morreale de Escobar G, 1987, Pyramidal cortical cell morphology studied by multivariate analysis, Effect of neonatal thyroidectomy, ageing and thyroxine-substitution therapy, Develop Brain Res, 37, 219-29.

15. Lauder JM, 1977, The effects of early hypo- and hyperthyroidism on the development of rat cerebellar cortex. III. Kinetics of cell proliferation in the external granular layer, Brain Res, 126, 31-51.

16. Maran RR, 2003, Thyroid hormones, their role in testicular steroidogenesis, Arch Andro/ 49, 375-88.

17. Maruo T, Katayama K, Barnea ER, Mochizuki M, 1992, A role for thyroid hormone in the induction of ovulation and corpus luteum function, Horm Res, 37, 12-8.

18. McGee EA, Hsueh AJW, 2000, Initial and cyclic recruitment of ovarian follicles, Endocrine Rev, 21, 200-14.

19. Nicholson IL, Altman I, 1972, The effects of early hypo- and hyperthyroidism on the development of rat cerebellar cortex. I. Cell proliferation and differentiation, Brain Res, 44, 13-23.

20. Obregon MJ, Mallol J, Pastor M, Morreale de Escobar G, Escobar del Rey F, 1984, L-thyroxine and 3,5,3-triiodthyronine in rat embryos before onset of fetal thyroid function, Endocrinology, 114, 305-7.

21. OECD, 2009, Guidance Document for Histologic Evaluation of Endocrine and Reproductive Test in Rodents OECD document, ENV/JM/MONO(2009)11 No.107.

22. Ortega $E$, Rodriguez $E$, Osorio $C$, 1990, Activity of the hypothalamo-pituitary ovarian axis in hypothyroid rats with or without triiodothyronine replacement, Life Sci, 46, 391-5.

23. Porterfield SP, Hendrich CE, 1993, The role of thyroid hormones in prenatal and neonatal neurological development - current perspectives, Endocrinol Rev, 14, 94-106.

24. Radovanović A, 1993, Efekat hipotireoidizma majki i perinatalnog hipertireoidizma na jajnike juvenilnih pacova, Magistarska teza, Fakultet veterinarske medicine, Univerzitet u Beogradu.

25. Radovanović $A, 2003$, Uticaj smanjene funkcije štitaste žlezde na jajnike pacova tokom polnog sazrevanja. Doktorska disertacija, Fakultet veterinarske medicine, Univerzitet u Beogradu.

26. Stephan DA, Menon RK, Franz B, Sperling MA, 1993, Thyroid hormone status correlates inversely with expression of the growth hormone receptor gene in rats immediately after birth, $J$ Dev Physiol, 19, 241-6.

27. Stošić-Bogdanović N, Radovanović A, 1992, The effect of hypothyroidism in pregnant and lactating dams on the testicles of juvenile pups, Acta Vet (Belgrade), 42, 99-108.

28. Tamura $K$, Hatsuta $M$, Watanabe G, Taya $K$, Kogo $H, 1998$, Inhibitory regulation of inhibin gene expression by thyroid hormone during ovarian development in immature rats, Biochem Biophys Res Commun, 242, 102-8.

29. Tilly JL, Tilly KI, 1995, Inhibitors of oxidative stress mimic the ability of follicle-stimulating hormone to suppress apoptosis in cultured rat ovarian follicles, Endocrinology, 136, 242-52. 
Acta Veterinaria (Beograd), Vol. 62, No. 5-6, 483-493, 2012.

Radovanović Anita et al.: Effects of induced maternal hypothyroidism

on the ovarian development of offspring rats

30. Zahedias/ S, 2010, Importance of thyroid hormones in intrauterine programming, Int J Endocrinol Metab, 8,186-7.

31. Zertashia A, Jalali S, Ahmad L, Mirza A, 2002, Effect of hypothyroidism induced by propylthiouracil on ovarian function and structure in offspring from treated mothers (rats), J Exp Zool, 293, 40713.

32. Zhang SS, Carrillo AJ, Darling DS, 1997, Expression of multiple thyroid hormone receptor mRNAs in human oocytes, cumulus cells, and granulosa cells. Mol Hum Reprod, 3, 555-62.

\section{UTICAJ INDUKOVANOG HIPOTIREOIDIZMA MAJKI NA RAZVOJ JAJNIKA MLADUNACA PACOVA}

RADOVANOVIĆ ANITA, ROKSANDIĆ D, ŠIMIĆ MARIJA, MARKOVIĆ DANICA i GLEDIĆ D

\section{SADRŽAJ}

U okviru ovog rada izučavan je uticaj hipotireoidizma majki izazvanog propiltiouracilom (PTU) tokom graviditeta i laktacije na razvoj i sazrevanje jajnika pacova. U cilju određivanja tireoidnog statusa majki i mladunaca, merena je koncentracija tireoidnih hormona i tireostimulirajućeg hormona (TSH) u serumu. Jajnici potomaka hipotireoidnih majki i kontolne grupe sprovedeni su za analizu svetlosnom mikroskopijom na dan prvog estrusa posle 60. dana starosti. Analizirani su serijski isečci jajnika bojeni hematoksilinom i eozinom, kao i polutanki preseci bojeni metilenskim plavim. Koncentracija $\mathrm{T}_{4}$ i $\mathrm{T}_{3}$ značajno je smanjena u serumu tretiranih majki, dok je nivo TSH značajno povišen u odnosu na kontrole. Kod dva meseca starih kontrolnih i tretiranih ženskih potomaka nije bilo značajne razlike u nivou svih određivanih hormona.

Deset procenata tretiranih životinja nije normalno ušlo u estrus do 60. dana, i žrtvovane su u fazi diestrusa. Sekundarne intersticijalne ćelije su dominantne strukture u jajnicima tretiranih pacova. Ukupan broj aktiviranih folikula je značajno smanjen uz izrazitu atreziju folikula, a smanjen je i broj žutih tela. Rezultati pokazuju da hipotireoidizam izazvan u toku graviditeta i laktacije dovodi do promena u razviću jajnika. 
